\title{
Supporting and Inhibiting Factors of Character Education in Learning Social Studies at Primary Schools
}

\author{
Hasnah Kanji ${ }^{1)}$, Nursalam ${ }^{2)}$, Muhammad Nawir ${ }^{3)}$, Suardi ${ }^{4)}$ \\ Master Program of Primary Education Universitas Muhammadiyah Makassar Indonesia ${ }^{1)}$ \\ Lecture of Study Program of Sociology Education FKIP Universitas Muhammadiyah Makassar, \\ Indonesia ${ }^{2,3,4)}$ \\ hasnahk10071987@gmail.com ${ }^{1)}$, nursalam.h@unismuh.ac.id ${ }^{2}$, m.nawir@unismuh.ac.id ${ }^{3)}$, \\ suardi@unismuh.ac.id ${ }^{4)}$
}

\begin{abstract}
The main problem of this study is that the students encounter a moral decadence which requires the integration support of character education in learning and anticipates various barriers to the integration of character education in learning. The purpose of this study was to identify various factors supporting and inhibiting character education specifically on social studies learning at primary schools. The research method used descriptive qualitative at SD Inpres 34 Bungung Katammu, Bantaeng Regency. In choosing the research informant, the researcher used purposive sampling, namely the principal, teachers, students and parents. Data collection technique used observation, depthinterview and documentation. Techniques of data analyzis were data reduction, data display and drawing conclusion. The technique of data validity was done through triangulation of sources, time and techniques. Based on the research findingsfrom various researchers, there has been no research which evaluates character education in learning of social study at primary schools which includes input, process and output of learning in high grade. The Factors in supporting and inhibiting character education at SD 34 Bungung Katammung consist of two aspects, namely internal and external. Supporting factors include teachers, principals (internal), parents (external) and inhibiting factors include teachers, principals (internal) and parents (external).
\end{abstract}

Keywords:Integration Mode, Character Education, Learning, Social Studies.

\begin{abstract}
Abstrak. Masalah utama dalam penelitian ini adalah kalangan pelajar mengalami dekadensi moral yang membutuhkan dukungan integrasi pendidikan karakter dalam pembelajaran dan mengantisipasi berbagai hambatan integrasi pendidikan karakter dalam pembelajaran. Tujuan penelitian ini untuk mengidentifikasi berbagai faktor pendukung dan penghambat pendidikan karakter terkhsusus pada pembelajaran ilmu pengetahuan social di sekolah dasar. Metode penelitian menggunakan deskriptif kualitatif SD Inpres 34 Bungung Katammu Kabupaten Bantaeng. Penentuan informan penelitian secara purposive sampling, yaitu kepala sekolah, guru, siswa dan orang tua. Teknik pengumpulan data menggunakan observation, depth-Interview dan dokumentasi. Teknik Analisis melalui data reduction, data display dan conclusion drawing. Teknik keabasahan data dilakukan melalui triangulasi sumber, waktu dan teknik. Bedasarkan hasil penelitian dari berbagai peneliti, belum ada penelitian yang melakukan evaluasi pendidikan karakter dalam pembelajaran ilmu pengetahuan sosial di sekolah dasar yang mecakup input, proses dan output pembelajaran di kelas tinggi. Faktor mendukung dan penghambat pendidikan karakter di SD 34 Bungung Katammung terdiri dari dua aspek yaitu internal dan eksternal. Faktor pedukungnya mencakup guru, kepala sekolah (internal), orang tua (eksternal) dan faktor penghambatnya mencakup guru, kepala sekolah (internal) dan orang tua (eksternal).
\end{abstract}

Kata Kunci: Model Integrasi, Pendidikan Karakter, Pembelajaran, Ilmu Pengetahuan Sosial. 


\section{INTRODUCTION}

Education is a conscious and systematic effort in developing the students potential students. Education is also an effort of the people and nation in preparing their young generation for the better life of the people and nation in the future. Sustainability is characterized by cultural and character inheritance that has been owned by the community and nation. Therefore, education is a process of cultural inheritance and national character for the young generation and also the process of developing the culture and character of the nation to improve the life quality of the people and nation in the future.

Education is a conscious and systematic effort to develop students' potential. (das sollen) the education implementation in a country is the responsibility of the state to implement it in the context of the intellectual life of the nation. Nevertheless, people also have the right to participate in the administration of education. The practice of education in our country indicates that the government (state), together with the people, is quite intense in the administration of education. For the smooth and successful education, it is stipulated in Law No. 2 of 1989 concerning with the national education system which was later amended by the issuance of Law No. 20 of 2003 concerning the national education system. This law is a benchmark for the government and the community in the education administration in Indonesia. Article
3 of Law No. 20 of 2003 asserted that national education functions to develop capabilities and shape the character and civilization of the nation that is useful in the context of educating life of the nation, aiming at developing the potential of students to become people of faith and devoted to God Almighty, having noble, healthy, knowledgeable, capable, creative, independent, and become citizens who are democratic and responsible. This was also confirmed by Ministerial Regulation, 22/2006 concerning content standards for primary and secondary education units. In order to achieve this goal, education is not only enough to emphasize the process and provision of facilities which lead to the mastery of science and technology (hard skills) but also have to facilitate the growth of noble characters as formulated in the national education goals above.

But the reality (das sein) among students now counter moral decadence which is very alarming as the behaviour of ethical, moral and legal crashing from the mild to the severe is still often shown by students (Ahya, H. 2013), cheating habits during tests or exams still being done (Akhwan, M. 2014), some symptoms occur among students in the form of delinquency (Unayah, N., \& Sabarisman, M. 2015), some of them are brawls between students.(Herawan, KD, \& Sudarsana, IK 2017), the increasing of violence among students (Pulungan, FR 2012), the more blurring of good and bad morals (Rohendi, E. 
2018), the decreasing work ethic (Arifin, I. 2017), lower respect to parents and teachers(Novitasari, K. 2017), the low sense of individual responsibilites and citizens (Suhono, S., \& Khumairo, A. 2018,), cultivating dishonesty (Rohendi, E. 2018,), the existence of mutual suspicion and hatred each other (Marlina, L., \& Nurman, G. 2017). In some big cities, student brawls become a tradition and form a fixed pattern, so that between them form a mortal enemy (Azmi, N. (2017),drink alcohol (Getting Drunk) (Tasik, F., \& Purwanto, A. 2018), promiscuity (Sudarsana, I. K. 2018), sucking glue (Simatupang, L. Y. 2018), hedonism (Tasik, F., \& Purwanto, A. 2018), drug abuse, (Soeroso, S. 2016), the rise of student gangs and motorcycle gangs (Qibtiyah, M. 2017), violence (bullying) (Amini, YSJ 2008) and even criminal acts such as, agitate,Persecution even murder(Rohayati, N. 2018), all of these are disgraceful acts (amoral) which do clearly not reflect our eastern customs and culture which are exacerbated by the incorporation of the teachers in internalizing character values (Ahmad, FY 2014) and the parents' difficulties in educating their childrencharacters (Daniel Goleman, 2000).

All of the negative behaviours among, these students clearly show a fairly severe fragility of character and one of them is caused by the suboptimal character development in educational institutions.In addition, environmental conditions that do not support character development and even hinder the development of student character education. For this reason, it is necessary to evaluate the supporting and inhibiting factors of character education conducted by educational institutions. This is important to support the development of human character and the Indonesian nation so that they ,for instance, have good, superior and noble character while eliminating various factors that can hamper character education at schools. Because institutions have an important role in developinga character education through school education (Ahya, H. 2013), because education has an important and central role in the development of human potential, including mental potential. It is expected that through education, there will be transformations which can foster positive character, and change thebad to goodcharacter. Ki Hajar Dewantara in Usman, H., \& Raharjo, N. E. (2012) firmly stated that education is an effort to advance the growth of character (inner strength, character), mind (intellect), and the child's body. Can be done in the learning process at school or college (Suardi, S dkk. 2019, Suardi, S dkk (2018) Suardi, S. 2018). Therefore the importance of character education to facilitate the reinforcement and development of certain values so that manifested in the behaviour of children, both during the school process and after the school process or after graduating from school (Kesuma, Triatna and Permana, 2011: 9). Education really needs to be done in 
the scope of schools, especially in social studies learning (Akhwan, M. 2014), basically, the purpose of social studies learning is to develop the potential of students to be able to adapt on the surrounding environment, be sensitive to the problems that occur in the community and be able to overcome both those that afflict themselves and those that affect the community and have a positive mental attitude towards correcting any inequality that occurs. Therefore, social studies play an important role in students' social interactions. To form characters in developing the potential that is beneficial to themselves, society, nation and country. Thus, social studies that are in direct contact with students' social lives need to be designed in such a way as to form personalities that are characterized by sustaining social experiences to build their potential. Besides, social studies are also designed to achieve common goals in forming relationships with social attitudes and skills. By conditioning conducive social studies learning, it will make students to be directly involved in learning to develop knowledge, values, attitudes, morals, and social skills. Students are able to participate in the dynamic life of modern society to approach the era of globalization as a millennial generation. In the end, the critical role carried by IPS (Social Studies) to form good citizens can be realized. So that social studies learning is not only designed and implemented, but it is also necessary to identify a variety of factors supporting and inhibiting systematic character education ranging from low grade to high grade in order to achieve these goals

The student potential is able to adapt to the surrounding environment, be sensitive to problems that occur in the community and be able to overcome both those that afflict themselves and those that affect the community and have a positive mental attitude towards correcting any inequality that occurs. Therefore, social studies play an important role on students' social interactions. To form characters at developing the potential that is beneficial to themselves, society, nation and country. Thus, social studies which are in direct contact with students' social lives need to be designed in such a way as to form Supporting and inhibiting factors of character education at schools, especially social science education in high grade is very important to do, because the high grade period at primary school ( 9 years to 12 years of age) included in grades IV, V, and VI has characteristics that are( 1) Have started to be independent; (2) There is already a sense of personal responsibility; (3) the evaluation of the outside world is not only seen from itself but also seen from others; (4) has shown a critical and rational attitude (Boojest, 2013). (5) Interest in life who did something concretely. (6) Very realistic, curious and want to learn; (7) Towards the end of this period there has been an interest in special matters or learning as the special talents begin to be emerged; (8) Until 
the age of 11, children need teachers or other adults to complete assignments and fulfil their desires. After this age,children generally face their tasks freely and try to complete them; (9) During this time the child views grades (report cards) as an appropriate measure of school performance, and; (10) Likes forming peer groups to play together. In the game they are no longer bound by traditional (existing) rules of the game, they make their own rules (Sebrinariz, 2014). So that the evaluation of character education at the high grade is very possible and results begin to appear.

\section{RESEARCH METHODS}

This research was a type of descriptive qualitative research that was to understand the phenomena about what was experienced by research subjects (Lexy J Moleong, 2007), with a deep understanding of individuals, groups or situations (Emzir, 2010: 20), describe, and map the facts based on a certain perspective or framework of thinking (Burhan Bungin, 2007). This research was conducted at SD Inpres 34 Bungung Katammu, Bissappu District, Bantaeng Regency, focusing on finding a model of integrating character education in learning social science. choosing the subject of this study was carried out using a purposive technique including principals, teachers, students and parents. In this study, the main instrument (key instrument) was the researcher himself serves to determine the focus of the study, chose the informant as a source of data, collect the data, assess data quality, analyze data, interpret data and make conclusions on its findings (Sugiyono, 2011). Data collection techniques used an observation (observation), in-depth interviews (depthinterview) and documentation. Techniques of Data Analysis in this study was by means of data reduction, data presentation and verification or drawing conclusions based on the findings. The data validity technique was done through source triangulation, time triangulation and technique triangulation.

\section{DISCUSSION}

\section{Supporting Factors integrating character} education in social studies learning at high grades (IV, V and VI)

a. Internal

The integration of character education in social studies learning at high grades (IV, V and VI) is obtained from various elements ranging from internal and external at school. Internal support is obtained from students, teachers, and school principals, while external support is obtained from parents in forming the student' character education in social studies learning at high class (grades IV, V and VI)

1) The teacher roles that became an important aspect in forming character education in social studies at high classes (grades IV, V and VI). The aspect which supports character education building in social studies at high classes (grades IV, V and $\mathrm{VI}$ ) is that the teacher becomes a target (row 
model) for students in learning process to provide examples of good behaviour whicht can be emulated by students. Among the examples given by the teacher such as (1) Religious character, the teacher participates in the Dhuha prayer with students every day, and the teacher reads short letters before starting the learning process. (2) Honest character, the teacher always tells the truth and gives correct information in learning process. (3) The character of tolerance, teachers always associate with teachers of different religions as a form of religious tolerance. (4) Discipline character, the teacher comes on time to teach in class and goes home according to the schedule determined by the school. Unless there are other sudden interests. Besides teacher uniforms are adjusted to the applicable rules such as Monday wearing official uniforms, Wednesday black and white uniforms, Saturday wearing sports uniforms. (5) The hard work, teachers always try to prepare learning tools for each meeting. (6) Creative character, the teacher makes learning media which are hung in the classroom and pinned to the classroom walls. (7) Independent character, the teacher conducts teaching activities independently in the class being taught. (8) Democratic character, teachers never discriminate between students who have different social and economic background.
(9) The curiosity character, the teacher always reads reference books and reads various writings available on the internet to add to the teacher's insight. (10) The character of the spirit of nationalism, the teacher teaches intending to educate the nation's children and advance the Indonesian State. (11) The character of patriotism, teachers always use Indonesian in teaching and use regional languages as a form of local wisdom. (12) Characters value achievement, the teacher always gives appreciation to students who have academic abilities in the classroom such as giving praise to students. Friendly/communicative character, the teacher likes to talk to students in class both in the learning process and outside the learning process. (14) The character of peace-loving, the teacher always tries to create a sense of security and peace in the classroom by teaching with a smile. (15) The character likes to read, the teacher gives examples of reading that is in learning and reading stories to students. (16) The character of caring for the environment, the teacher always picks up trash and cleans the room inside and outside the classroom. (17) The character of social care, the teacher helps students in the class, for students who faces difficulties or problems in learning. (18) The character of responsibility, the teacher always teaches at predetermined 
hours and learning every semester which is the teacher's responsibility

2) The aspects of the head master who can be as a important aspect in forming a character education in social studies in high classes (class IV, V and VI). And evaluation of the planning and implementation of learning that has been prepared by the teacher so that, it always includes character education. In addition, other contributions are school policies which can support character education such as (1) Religious characters, the principal leads students to read short letters in the school field. (2) Honest character, the principal always tells the truth and gives information to the teachers and students. (3) tolerance Character, principals always associate with teachers of different religions as a form of religious tolerance. In addition, the headmaster answered greetings from teachers and students in different religions. (4) Discipline character, the principal comes on time to school. Unless there are other sudden interests. In addition, the principal's uniform is adjusted to the applicable rules such as Monday wearing official uniforms, Wednesday black and white uniforms, Saturday wearing sports uniforms. (5) Hardwork character, the principal tries to monitor teacher learning tools. (6) Creative character, the principal makes a policy to create learning media which are hung in the classroom and attached to the classroom walls. (7) Independent character, the principal conducts school management activities independently without the vice principal. (8) Democratic character, principals never discriminate between teachers and students who have different social and economic status backgrounds. (9) Character of curiosity, the principal always reads a variety of writings which are found from the internet to add insight to the principal, including news which is on facebook and WhatsApp. (10) The spirit character of the nationalism, the principal leads the school with the aim to make indonesian students clever and make Indonesia stronger

(11) Always use Indonesian when giving direction or guidance to teachers and staff. (12) Appreciation Character of achievement, the principal always gives an appreciation for teachers who have achievements in teaching. (13) Friendly or communicative character, the principal likes to talk to teachers inside the office room and outside the office. (14) The character of peace-loving, the principal tries to create a sense of security and peace in the school environment by always establishing communication with all teachers. (15) The character likes to read, the principal gives an example to the teacher to use mobile technology to find information. (16) The character of caring for the environment, the principal provides 
support in the form of policies to create a clean school environment. (17) The character of social care, the principal helps teachers, students and parents of students who experience a problem. (18) The character of responsibility, the principal leads the school management which is the the pricipal responsibility.

3) The Student Factors that become important aspect in forming character education in social studies at high classes (grades IV, V and VI). Namely as peer tutors in giving examples by other students a good behaviours such as (1) Religious characters, students participate in the Duha prayer with other students every Friday, and students read holy Qur'an before starting the teaching and learning process. (2) Honest character, students are honest and give correct information to the teacher and other students in teaching and learning process. (3) The character of tolerance, students always associate with other students with different socio economic status and with teachers of different religions as a form of religious tolerance. (4) Discipline character, the majority of students arrive on time to study in class and go home according to the schedule determined by the school. Besides, students are disciplined in wearing school uniforms because student uniforms are adjusted to the applicable rules. Like Monday wearing a red and white heart uniform, Wednesday and Thursday batik uniforms, Friday and Saturday wearing paramuka uniforms and wearing sports uniforms according to the schedule of sports learning. (5) The character of hard work, students always try to prepare writing instruments before starting the lesson, including working hard in doing the tasks given by the teacher. (6) Creative characters, students are involved in making learning media that are made together with the teacher who is hung in the classroom and placed in the classroom walls as a learning media resulting from the teacher and student creativity. (7) Independent character, students do learning activities independently in class if they are doing independent assignments from the teacher. (8) Democratic character, each student learns in class without discrimination against other students because they have the same rights in learning. (9) The character of curiosity, students read textbooks given by the teacher to add students insight (10) Character of national spirit, students learn to be smart children and useful for parents and the nation. (11) The character of patriotism, students use Indonesian to communicate in class and only occasionally use local languages inside and outside the classroom, this is done as a form of love for local wisdom. (12) Appreciation Character of achievement, student gives appreciation for the students who are smart in class by giving praise. (13) Friendly/communicative 
character, the students, inside and outside the classroom both in the learning process and outside the learning process are stiil respect each other. (14) The character of peace-loving, students try to create a sense of security and peace in the classroom by not disturbing other friends. (15) Character likes reading; students read the teks given by the teacher before and during the teaching and learning process in the class. (16) The character of caring for the environment, students always pick up trash and clean the inside and outside of the classroom. Keep shoes on a shoe rack in the classroom to keep the classroom clean. (17) The character of social care, students help other students in the class, for students who face difficulties or problems in learning. (18) The character of responsibility, students carry out their obligations in the classroom such as diligent in learning as the student responsibility.

b. External

Parent factor that become a important aspect in supporting and forming character education in social sciences at high grade (class IV, V and VI). Parents who support forming of character education in the family or community environment, namely the commands/recommendations and prohibitions or rules set by parents are not written in the form of social norms in the family, which become a reference and guide for all family members, especially children to do good things, namely (1) Religious character, parents always pray five times a day both at home and at prayer pray at the mosque. (2) Honest character, parents always teach honesty, say the right thing even if it hurts. (3) The character of tolerance, parents always teach their children to respect their teacher's despite being of different religions as a form of religious tolerance. (4) Discipline character, parents discipline to wake their children to go to school on time so that they are not late. (5) The character of hard work, parents always try as hard as possible to provide support to students to take education both in terms of cost, time and energy. (6) Creative characters, parents make student learning tools made by parents such as making student desks, sewing children's shoes and sewing is children's uniforms. (7) Independent character, parents finance their children's school needs independently, without being dependent on other families. Democratic character, parents never discriminate between their sons or daughters. (9) The character of curiosity, parents always ask the teacher, related to information on their learning progress when meeting with their child's teacher. (10) The character of the spirit of nationalism, parents send their children to school intending to make their children useful for the family and the country. (11) 
The loving character of the motherland, parents sometimes use Indonesian when talking to their children, even though they use language more in interacting with their children. (12) Appreciation Characters, parents always give motivation their children to study hard so that they become smart children. (13) Friendly/ communicative character, parents like to talk with their children before leaving and after returning from school. (14) Peaceloving character, parents always try to create a sense of security and peace in their home with love and affection. (15) The character likes to read, parents give examples to their children if there are things that are not understood by their children by reading student textbooks. (16) The character of caring for the environment, parents teach their children to throw garbage behind the house and clean the house. (17) The character of social care, parents help their children and other students who face many difficulties or problems in learning. (18) The character of responsibility, parents educate thechildren if at home properly as a form of their responsibilities as parents.

\section{Integration inhibiting factors of character education in social studies learning at high grades (IV, V and VI)}

a. Internal

The integration of character education in social studies learning at high grades (IV, V and VI) not only gets support from various elements but also gets obstacles from various elements ranging from internal and external school. Internal barriers were obtained from students, teachers, principals, while external barriers were obtained from parents in forming the student character education in social studies learning at high grade classes (grades IV, V and VI).

1) Teacher factors that become obstacles in building character education in social studies at high classes (grades IV, V and VI). The thing that becomes an obstacle in building character education in social studies at high classes (grades IV, V and VI) is that all teachers should ideally become a leader for all students, by displaying various feelings, knowledge, or actions that contain character values but there are actions which conducted by teachers who can inhibit character education, those were the three teachers observed by researchers, namely: (1) Inhibiting religious character from growing in students because those are some teachers do not participate Dhuha prayer with students. (2) Inhibiting the character of discipline growing in students, because those are some teachers who are not present on time to teach in the class room and those are also some teachers who never go home on time. Besides there are also teachers who wear uniforms teachers which do not comply with applicable rules. (3) Inhibiting 
the character of hard work to grow in students because there are teachers who have taught students with repetitive material, this indicates, the teacher did not show a hard effort to prepare the learning tools. (4) Inhibiting the character of curiosity growing in students because, there are teachers who teach learning that are still using old books, not trying to find new knowledge that can be taught to students. (5) Inhibiting the character of social care growing in students because, there are teachers who do not help students in the class, even though the student is experiencing difficulties or problems in learning. However, teachers only compare these students with other students without providing assistance or solutions to students. (6) Inhibiting the character of responsibility to grow in students because there are teachers who have never entered teaching according to what is determined by the teacher.

2) School principals who become obstacles in building character education in social studies at high classes (grades IV, V and VI) namely: (1) Inhibiting religious character from growing in students because principals have never participated in the Duha prayer because Christian school principals are different from religion of all students who are Muslim. (2) Inhibiting the character of discipline from growing in students because the principal did not present to carry out the flag ceremony.

3) Students who become supporters in the formation of character education in social studies in high classes (grades IV, V and VI). Students who hinder the formation of character education in social studies in high classes (grades IV, V and VI), namely student behaviour that is not good to be imitated by students such as (1) Inhibiting the character of discipline growing in students because there are students who present on time to study in the class room and go home according to the schedule determined by the school. In addition, there are also students not disciplined in wearing school uniforms because student uniforms are adjusted to the applicable rules. (2) Inhibiting the character of hard work growing in students because there are students who have never done the assignments given by the teacher. (3) Inhibiting the character of curiosity growing in students because there are students who are still not fluent students reading textbooks given by the teacher ( 4 Inhibiting the character of friendly/communicative growing in students because there are students who are hostile in the classroom.

b. External

the Parents factors who become obstacles in building a character education in social studies at high classes (class IV, V and 
VI). Parents who inhibit the building of character education in the family environment that is the behaviour of parents who are not good to be imitated by children, from three parents of students who observed such as (1) Religious characters, some parents do not carry out five prayers starting from prayer sunset, evening prayer, dawn prayer, midday prayer, and asr prayer. (2) Honest character, some parents deceive their children because they do not want to give money and finally say there is no money even though the money is there. (3) The character of patriotism, some parents communicate with their children not using Indonesian but by using local languages that contain unethical words such as using the word "KO" to children, even though the word is forbidden by students. (4) Lovingreading characters, some parents are not used to reading books that can be taught to their children. (5) The character of caring for the environment, some parents throw away the sampan both organic and non-organic garbage around the house.

\section{CONCLUSION}

Supporting and inhibiting factors in character education at SD 34 Bungung Katammung consists of two aspects, namely internal factors and external factors. Factors are supporting the integration of character education in social science in high classes (IV, $\mathrm{V}$ and VI) include teachers, principals (internal) and parents (external). While the inhibiting factor also consists of teachers, principals (internal) and parents (external) who indirectly provide examples of behaviour that can inhibit the development of student character, because students imitated the teacher behaviour, principals and parents as role models for themselves

\section{REFERENCES}

[1] Ahmad, T. A. 2014. Kendala Guru dalam Internalisasi Nilai Karakter pada Pembelajaran Sejarah. Khazanah Pendidikan, 7(1).

[2] Ahya, H. 2013. Pendidikan Karakter di SMA Santo Bonaventura Madiun (Doctoral dissertation, University of Muhammadiyah Malang).

[3] Akhwan, M. 2014. Pendidikan Karakter: Konsep dan Implementasinya dalam Pembelajaran di Sekolah/Madrasah. El Tarbawi, 8(1), 61-67.

[4] Amini, Y. S. J. 2008. Bullying: mengatasi kekerasan di sekolah dan lingkungan sekitar anak. Grasindo.

[5] Arifin, I. 2017. Kompetensi Kepribadian Kepala Sekolah Berbasis Moral Spiritual dalam Mengimplementasi Pendidikan Karakter.

[6] Ariyani, Neni \& Wismiarti. 2004. Panduan Pendidikan Sentra untuk PAUD. Jakarta: CCCRT.

[7] Azmi, N. 2017 Manajemen Pendidikan Karakter Siswa Man 1 Brebes dan MAN 2 Brebes. Purwekerto: Institut Agma Islam Negeri Purwerkerto.

[8] Badan Penelitian dan Pengembangan, Kemenpan. 2011. Panduan Pelaksanaan Pendidikan Karakter. Jakarta: Pusat Kurikulum dan perbukuan.

[10] Boojest. 2013. Karakteristik Siswa Sekolah Dasar (online) https://jejecmsbhnajar.wordpress.com/2013/ 04/23/karakteristik-dan-perkembangan- 
belajar-siswa-di-sekolah-dasar/. Diakses tanggal 27 bulan Mei Tahun 2019.

[11] Cahyono, H., Suhono, S., \& Khumairo, A. 2018. Pendidikan Karakter Bagi Pelaku Pedofilia (sebuah Strategi dalam Mengatasi Amoral). JMKSP (Jurnal Manajemen, Kepemimpinan, dan Supervisi Pendidikan), 3(1).

[12] Departemen Pendidikan Nasional. 2003. Undang-Undang Nomor 20 Tahun 2003, Tentang Sistem Pendidikan Nasional. Jakarta: Depdiknas.

[13] Depdiknas. 2006. Permen Nomor 22 Tahun 2006. Jakarta: Depdiknas.

[14] Echols, John M dan Hassan Shadily. 2014 Kamus Inggris-Indonesia. Jakarta: PT. Gramedia.

[15] Emzir. 2010. Metodologi Penelitian Kualitatif Analisis Data. Jakarta: Raja Grafindo Perkasa.

[16] Goleman, Daniel. 2000. Working With Emotional Intelligence (Terjemahan Alex Kantjono W)". Jakarta: PT Gramedia Pustaka Utama.

[17] Gunawan, Heri. 2012. Pendidikan Karakter (Konsep Dan Implementasi). Bandung: Alfabeta.

[18] Herawan, K. D., \& Sudarsana, I. K. 2017. Relevansi Nilai Pendidikan Karakter Dalam Geguritan Suddhamala Untuk Meningkatkan Mutu Pendidikan Di Indonesia. Jurnal Penjaminan Mutu, 3(2), 223-236.

[19] Kesuma, Dharma, Dkk. 2011. Pendidikan Karakter, Kajian Teori dan Praktik di Sekolah. Bandung: PT Remaja Rosdakarya Offset.

[21] Lickona, Thomas (2012) Education for Character: Mendidik untuk Membentuk Karakter. Jakarta: PT Aksara.

[22] Losa, J., Tasik, F., \& Purwanto, A. 2018. Peranan Orang Tua dalam Mengatasi Kenakalan Remaja Akibat Meminum Alkhohol Cap Tikus (Studi Kasus di Desa Talawaan Kecamatan Talawaan Kabupaten
Minahasa Utara)". JURNAL Administrasi Publik, 1(043).

[23] Marlina, L., \& Nurman, G. 2017. Pengembangan Pendidikan Karakter Dan Kebangsaan Di SMK Pab 1 Helvetia.

[24] Megawangi, Ratna. 2006. Pendidikan Yang Patut Dan Menyenangkan. Jakarta: Viscom Pratama.

[25] Moleong, Lexy J. 2013. Metode Penelitian Kualitatif. Edisi Revisi. Bandung : PT. Remaja Rodaskarya.

[26] Novitasari, K. 2017. Pembelajaran Berbasis Proyek untuk Menanamkan Karakter Tanggung Jawab pada Anak Kelompok B Di Tk Nasima Kota Semarang. PG PAUD Universitas PGRI Yogyakarta.

[27] Pulungan, F. R. 2012. Pengaruh Model Pembelajaran Problem Based Learning Berbasis Pendidikan Karakter terhadap Perubahan Karakter dan Kemampuan Menyelesaikan Masalah Fisika. Jurnal Penelitian Inovasi Pembelajaran Fisika, 4, 38-43.

[28] Qibtiyah, M. 2017. Manajemen pendidikan Madrasah Aliyah Binaan Pesantren dalam Pengembangan karakter Peserta Didik. Jurnal Bimbingan dan Konseling ArRahman, 2(1).

[29] Rohayati, N. 2018. Peranan Muhammadiyah Dalam Membina Generasi Muda Melalui Pendidikan Karakter Di Sukajadi Kota Bandung. Empowerment, 2(2), 116-125.

[30] Rohendi, E. 2018. Mengembangkan Sikap dan Perilaku Anak Usia Dini melalui Pendidikan Berbasis Karakter. Cakrawala Dini, 3(1).

[31] Sebrinariz. 2014. Karakteristik dan Ciri Khas Anak SD Serta Implikasi Terhadap Pendidik (Online)

http://sabrinariz.blogspot.co.id/2014/05/kara kteristik-dan-ciri-khas-anak-sd.html. Diakses tanggal 27 bulan Mei Tahun 2018.

[32] Simatupang, L. Y. 2018. Perilaku Menyimpang Para Remaja Penghisap Lem di Kelurahan Pasar Merah Barat Kecamatan Medan Kota Sumatera Utara. 
[33] Sudarsana, I. K. 2018. Membina Kerukunan Antar Siswa Di Sekolah Melalui Penanaman Pendidikan Budi Pekerti Berbasis Kearifan Lokal. In Prosiding Seminar Nasional Kearifan Lokal Indonesia Untuk Pembangunan Karakter Universal 2015 (pp. 242-250).

[34] Sugiyono. 2014. Metode Penelitian Kuantitatif Kualitatif dan $R \& D$. Bandung: Alfabeta.

[35] Suardi, S., Herdiansyah, H., Ramlan, H., \& Mutiara, I. A. (2019). Implementasi Pendidikan Karakter Melalui Mata Pelajaran Pendidikan Kewarganegaraan di SMA Jaya Negara Makassar. JED (Jurnal Etika Demokrasi), 4(1).

[36] Suardi, S., Megawati, M., \& Kanji, H. (2018). Pendidikan Karakter di Sekolah (Studi Penyimpangan Siswa di Mts Muhammadiyah Tallo). JED (Jurnal Etika Demokrasi), 3(1).

[37] Suardi, S. (2018). Penerapan Model Pembelajaran Saintifik Approacd Berbasis Media Pembelajaran Kearifan Lokal pada Mata Kuliah Dasar-Dasar Sosiologi dalam Membangun Karakter dan Meningkatkan Hasil Belajar Mahasiswa Pendidikan Sosiologi Universitas Muhammadiyah Makassar. JED (Jurnal Etika Demokrasi), 3(2).

[38] Triestuning, E., Wachid, W., \& Sari, L. N. (2016). Gambaran Sikap Remaja Dalam Mengkonsumsi Minuman Keras Di Desa Sidowayah RW. 05 Sidoarjo. Nurse and Health, 5(2), 4-6.

[39] Usman, H., \& Raharjo, N. E. 2012. Model Pendidikan Karakter Kewirausahaan di Sekolah Menengah Kejuruan. Jurnal Pendidikan Teknologi dan Kejuruan, 21(2). 